\title{
A single breath-hold for analysis of systolic and diastolic cardiac function: TGRAPPA accelerated multiplanar Cine MR imaging at 3 \\ Tesla

\author{
Torleif A Sandner*, Daniel Theisen, Kerstin U Bauner, Konstantin Nikolaou, \\ Maximilian F Reiser and Bernd J Wintersperger
}

Address: University Hospitals of Munich, Grosshadern Campus, Munich, Germany

* Corresponding author

from 13th Annual SCMR Scientific Sessions

Phoenix, AZ, USA. 21 -24 January 2010

Published: 21 January 2010

Journal of Cardiovascular Magnetic Resonance 20 I0, I2(Suppl I):P85 doi: I0.I I86/I532-429X-I2-SI-P85

This abstract is available from: http://jcmr-online.com/content/I2/SI/P85

(c) 2010 Sandner et al; licensee BioMed Central Ltd.

\section{Introduction}

CMR is the standard of reference in cardiac functional analysis. However, long data acquisition time which necessitates repeated breath-holding results in extended overall examination time. Furthermore post-processing of standard short axis cine data for evaluation of systolic and diastolic function is rather time-consuming.

\section{Purpose}

The aim of this study was to evaluate the accuracy of a recently introduced TGRAPPA accelerated single-breathhold multi-planar cine approach for analysis of systolic and diastolic left ventricular function at $3 \mathrm{~T}$.

\section{Methods}

23 patients underwent cine MRI at 3 Tesla (Magnetom Verio) using a 32-element cardiac coil for signal reception. In all patients a stack of short axis slices was acquired using a standard non-accelerated cine SSFP technique (STANDARD) with $8 \mathrm{~mm}$ slice thickness and a $2 \mathrm{~mm}$ interslice gap. In addition a multi-planar cine SSFP data set based on three short axis slices, a vertical and a horizontal long axis slice was acquired within a single-breathhold using a 4-fold accelerated cine SSFP technique (TGRAPPA). 4D analysis of the multi-planar data sets was performed using a commercially available algorithm (syngo ARGUS 4D) with long axis definition of the AV valvular planes. $4 \mathrm{D}$ data was compared with the standard single-slice technique (syngo ARGUS) according to the
Simpsons' rule for end-diastolic volume (EDV), endsystolic volume (ESV), ejection fraction (EF), myocardial mass (MM), peak filling rate (PFR) and peak ejection rate (PER). All data were evaluated by two independent readers. In addition time intervals necessary for data acquisition as well as for data post-processing were recorded.

\section{Results}

The TGRAPPA approach did not exhibit any significant differences to the STANDARD approach for $\operatorname{EF}(61.7 \pm$ 12.5 vs. $64.1 \pm 10.5 \% ; \mathrm{P}=.12), \mathrm{EDV}(123.8 \pm 40.5$ vs. $129.9 \pm 48.3 \mathrm{ml} ; \mathrm{P}=.12), \operatorname{ESV}(50.0 \pm 34.1$ vs. $49.4 \pm 32,2$ $\mathrm{ml} ; \mathrm{P}=.83)$ and $\mathrm{MM}(126.7 \pm 34.9$ vs. $121.5 \pm 37.2 \mathrm{~g} ; \mathrm{P}=$ $.03)$. Diastolic evaluation using the $4 \mathrm{D}$ technique though revealed significant differences for PER $(564.8 \pm 204.1 \mathrm{vs}$. $366.8 \pm 82.0 ; \mathrm{P}=.001)$ and PFR (535.6 \pm 244.6 vs. 269.9 $\pm 108.4 ; \mathrm{P}=.03$ ). The coefficient of variation was 10.49 for $4 \mathrm{D}$ EF and 3.98 for STD EF analysis showing a significant higher variation of parameters for the multi-slice approach. Time-efforts for acquisition (273.5 \pm 124.5 vs. $12.4 \pm 3.1 \mathrm{sec})$ and post-processing $(15.2 \pm 5.4$ vs. $5.7 \pm$ $2.3 \mathrm{~min}$ ) were significantly shorter for the TGRAPPA $4 \mathrm{D}$ cine $(\mathrm{P}<0.001)$.

\section{Conclusion}

Multi-planar single breath-hold cine acquisition at 3 Tesla facilitates significantly shorter analysis of ventricular function. This approach may substantially speed up workflow for assessment of cardiac function at $3 \mathrm{~T}$. Diastolic param- 
eters especially may show off-sets to standard techniques based on model differences.

Publish with Bio Med Central and every scientist can read your work free of charge

"BioMed Central will be the most significant development for disseminating the results of biomedical research in our lifetime. " Sir Paul Nurse, Cancer Research UK

Your research papers will be:

- available free of charge to the entire biomedical community

- peer reviewed and published immediately upon acceptance

- cited in PubMed and archived on PubMed Central

- yours - you keep the copyright

Submit your manuscript here:

http://www.biomedcentral.com/info/publishing_adv.asp 